\title{
ASSESSMENT OF GROUNDWATER QUALITY FOR IRRIGATION AT MALAMAWI ISLAND, BASILAN, PHILIPPINES
}

\author{
Alejandro A. Jalil ${ }^{1}$, Roger A. Luyun, $\mathrm{Jr}^{2}$, Aurelio A. Delos Reyes, $\mathrm{Jr}^{2}$.,and Victorino A. Bato ${ }^{3}$, \\ ${ }^{1}$ College of Agriculture and Fisheries, Basilan State College, Isabela City, Basilan, Philippines \\ ${ }^{2}$ Land and water Res. Div., Inst. of Ag. Eng'g, College of Engineering and Agro-industrial \\ Technology, University of the Philippines, Los Banos, Philippines \\ ${ }^{3}$ Department of Soil Science, College of Agriculture, UPLB, Philippines
}

Email : aajalil@up.edu.ph

Submitted: 22 February 2020; Revised: 26 October 2020 Accepted: 14 December 2020

\begin{abstract}
The assessment of groundwater quality for agricultural purposes was conducted in Malamawi Island, Isabela City, Basilan. Groundwater quality wasevaluated based on the FAO irrigation quality standards (1994)which include salinity and alkalinity, sodium, magnesium, bicarbonate hazards and chloride hazards. Spatial delineation of groundwater quality parameters was carried out using QGIS software. Results revealed that the use of groundwater from two separate sampling wells (SW4 and SW6) in Lukbuton area require slight to moderate restrictionbased on the parameters of electrical conductivity and magnesium hazard. This means that its groundwater can still be safe for irrigation but with little salinity hazard on sensitive crops.Also, the chloride concentration in SW4 indicates that groundwater was slightly poor in quality but generally suitasble for irrigation while in SW6, the calcium concentration was considered unsuitable for irrigation. In the same way, the sampling wells 1 and 3 in Santa Barbara and Lukbuton were considered unsafe and unsuitable for irrigation in terms of magnesium hazard. Also, the calcium content of groundwater in some part of the island was considered unsuitable for irrigating high-value crops. Therefore, this study suggests that some management is needed in the northeastern part of Lukbuton because of its poor ground water quality for irrigation in terms of salinity.
\end{abstract}

Keywords: Malamawi, Basilan, irrigation, shallow well.

\section{ABSTRAK}

Penilaian kualitas air tanah untuk keperluan pertanian dilakukan di Pulau Malamawi, Kota Isabela, Basilan. Kualitas air tanah dievaluasi berdasarkan kesesuaian untuk irigasi sesuai standar kualitas irigasi FAO meliputi salinitas dan alkalinitas, serta bahaya natrium, magnesium, bikarbonat dan klorida. Delineasi spasial dari parameter kualitas air tanah dilakukan dengan menggunakan perangkat lunak QGIS. Hasil penelitian menunjukkan bahwa penggunaan airtanah dari dua sumur sampel terpisah (SW4 dan SW6) di kawasan Lukbuton memerlukan pembatasan ringan hingga sedang berdasarkan parameter 
konduktivitas listrik dan bahaya magnesium. Hal ini menunjukkan air tanah masih aman untuk irigasi walaupundengan sedikit bahaya salinitas untuk tanaman yang sensitif. Selain itu, konsentrasi klorida di SW4 menunjukkan bahwa kualitas airtanah agak buruk walaupun umumnya cocok untuk irigasi sedangkan di SW6, konsentrasi kalsium dianggap tidak sesuai untuk irigasi. Dengan cara yang sama, pengambilan sampel sumur 1 dan 3 di Santa Barbara dan Lukbuton dianggap tidak aman dan tidak cocok untuk irigasi dalam hal bahaya magnesium. Selain itu, kandungan kalsium air tanah di beberapa bagian pulau dianggap tidak sesuai untuk mengairi tanaman bernilai ekonomi tinggi. Oleh karena itu, studi ini menyarankan bahwa perlu dilakukan pengelolaan di bagian timur laut Lukbuton karena kualitas air tanah yang buruk untuk irigasi dari segi salinitas.

\section{Kata kunci: Malamawi, Basilan, irigasi, sumur dangkal}

\section{INTRODUCTION}

Groundwater qualityis essential for human life and inherent for economic vitality. It is also one of the most crucial factors for groundwater irrigation (Jang et al., 2012; Jang et al., 2019). However, during the hydrological cycle, metals and other impurities were introduced in the water bodies through anthropogenic activities such as the use of agrochemicals (pesticides and fertilizers), coal combustion, and other low-quality fuel in brick kilns and other industries, untreated industrial effluents discharge, and the improper disposal of municipal solid wastes (Nawab et al., 2018; Naseh et al., 2018; Khanoranga \& Khalid, 2019).

These activities may affect the quality of groundwater for irrigation. Highly contaminated irrigation water can cause changes in soil permeability, soil $\mathrm{pH}$, soil structure and nutrient uptake by plants (A. B. Iqbal et al., 2020). The excessive sodium dissolution in irrigation water can lead to the soil's higher Sodium Adsorption Ratio (SAR)making it less suitable for irrigation. Also, the presence of bicarbonates $\left(\mathrm{HCO}_{3}\right)$ and carbonates $\left(\mathrm{CO}_{3}{ }^{-}\right)$in the water tend to increase the
$\mathrm{pH}$, making it inimical for plant growth.Bicarbonates in the irrigation water has become a serious concern because it increases the $\mathrm{pH}$ from 7.4 to 9.3 (ibid.). According to Alobaidy et al. (2010), a significant factor that escalates water $\mathrm{pH}$ to 8.0 and beyond is due to the presence of carbonates. This significant amount in the irrigation water can directly harm some plant species. Therefore, the poor water quality can adversely affect plant growth regardless of its quantity (Alobaidy et al., 2010).

Because of that, there is a need to ascertain the groundwater quality before it can be used for irrigation purposes to ensure optimum levels of plant growth (Mitra et al., 2007).Part of this is to understand the groundwater characteristics through the monitoring and assessment of water's quality apt for drinking, agricultural, and industrial uses (Adimalla et al., 2019; Kuldip-Singh et al., 2011; Adimalla et al., 2020). It is also important to determine the amount and kind of salt present in the water because poor water quality tends to cause various cropping problems. The suitability of groundwater irrigation depends on the 
salinity, conductivity, and hardness of water ((Singh \& Khare, 2008). Among the major cations to be monitored include calcium, magnesium, and sodium which also influence the suitability of groundwater for irrigation. These cations can be toxic to plants, affect soil properties and management practices, but can also be beneficial to crop production at desirable concentrations (FAO, 1994).

In Malamawi Island in Basilan, all crops grown are rain-fed. However, there is still a need to determine whether the groundwater quality is suited for irrigation. There is also a possibility to recommend an installation of artificial irrigation system to intensify crop production if the groundwater quality is suitable for irrigation. Therefore, this study was conducted to assess the quality of shallow ground water in six sampling wells in the island to determine its suitability for agricultural purposes based on the standard water quality guidelines of Food and Agriculture Organization (1994), and spatially mapped each groundwater quality parameter through interpolation using QGIS to present its concentration in the entire Island. The results of the study may serve as baseline information particularly the current measured parameter concentrations in Malamawi Island, Basilan.

\section{MATERIALS AND METHODS}

\section{A. The Study Area}

Malamawi Island (Figure 1) is about $300 \mathrm{~m}$ from the main island of Basilan. It has a total delineated area of about 947 Has. The island consists of seven different villages which islocated between 6042'46" $\mathrm{N}$ and 6044'45" N latitudes, 121056'24" E and 121058'23" E longitudes. The general elevations ranged from $5 \mathrm{~m}$ to $103 \mathrm{~m}$ above sea level while slopes ranged from $3 \%$ to $30 \%$. The island has a current population of 13,859 with most houses built along the shoreline.

The island is dominated by agricultural activities. Most areas are planted with coconut, mango, and citrus trees (Figure 2 ). The hilly portions were regularly planted with small-scale root crops and vegetables. Almost all of the entirearea that consists of Bulawan clay loamare cultivated with rice, corn, and coconut. The island has a type Illclimate classification, where the seasons are not very pronounced, relatively dry from November to April, and wet during the rest of the year (Bangsamoro Development Agency, 2016). The annual mean temperature and precipitation is $26.6^{\circ} \mathrm{C}$ and $1,100 \mathrm{~mm}$ respectively (Bangsamoro Development Agency, 2016). 

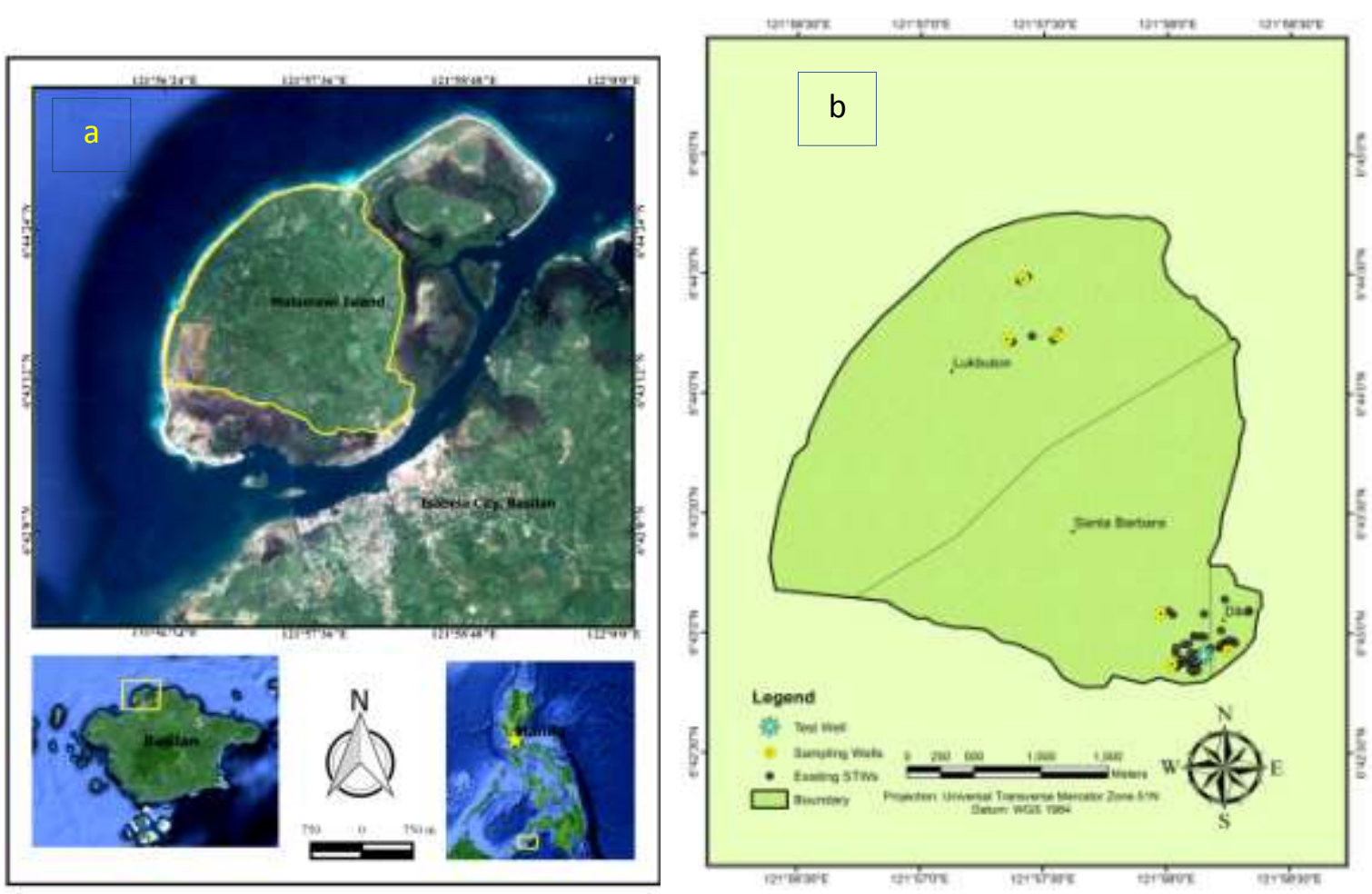

Figure 1. Location maps, a. Study area (Source: Google Earth, 2015) and, b. Sampling and existing Shallow wells in Malamawi Island, Isabela City, Basilan, Zamboanga Peninsula,Philippines

\section{Land use Classification of Malamawi, Basilan}
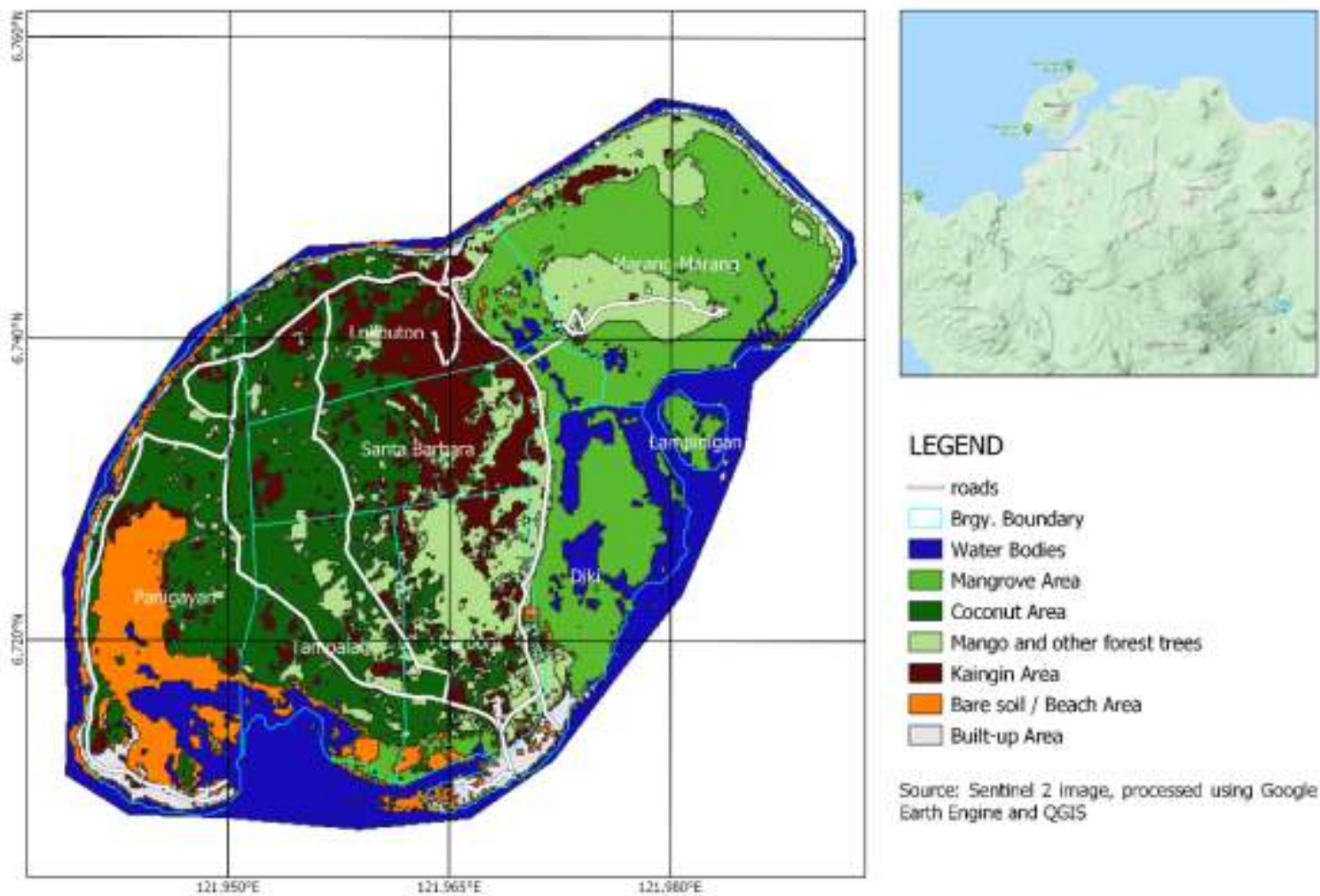

LEGEND

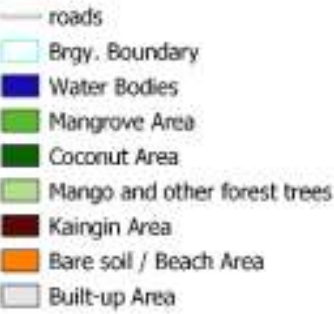

Source: Sentinel 2 image, processed using Gocole Earth Engine and QGS

Figure 2. Land Use Classification Mapof Malamawi Island, Basilan, Zamboanga Peninsula, Philippines 


\section{B. Indicators of Water Quality for Irrigation}

Important irrigation water quality parameters include several specific properties of water related to the yield and quality of crops, maintenance of soil productivity, and protection of the environment. These parameters consist mainly of the water's physical and chemical characteristics used in the evaluation of agricultural water quality (Alobaidy et al., 2010). The FAO (1994) water quality guidelines were used to assess the suitability of groundwater for irrigation in Malamawi Island.

The indicators used were: (1) salinity, (2) calcium hazard, (3) sodium hazard, (4) soluble sodium percentage (SSP), (5) magnesium hazard, (6) residual sodium carbonate (RSC), and (7) chloride hazard. The equation tocompute some indices of the groundwater of the island for agricultural purposes is listed in Table 1, while Table 2 showed the criteria used to asses the water quality.

\section{Sampling and Analysis}

Six groundwater shallow well samples were collected on March 2014 out of ninety-four (94) existing wells in Malamawi Island (Figure 1b). One sampling well was selected from each clustered well located within the island. Since the wells have similar depths it was assumed that each well taps the same aquifer. The sample water taken from the well is a representative of the groundwater quality within the clustered area. Purging of about two (2) minutes was done before the samples were collected. Before collecting the groundwater, the sampling bottles were thoroughly cleaned using a detergent. A total of 1.5 of water samples were collected from each well. Following the standard procedures litters set by the Philippine National Standard for Drinking Water (PNSDW, 2017), filled bottles were tightly capped and properly labeled with the following information: 1) date and time of sampling, and 2) source of the sample. Sampling bottles were placed in an icebox at low temperature to prevent any unnecessary chemical reactions. The water samples were transported to DOSTIX, Regional Standards and Testing Laboratories, Zamboanga City Water District, and Zamboanga State College of Marine Sciences and Technology for analysis. Potassium and sodium were measured using a direct air-acetylene flame method (acid digestion)/ standard method 3111 B, Standard Methods for the Examination of Water and Wastewater (SMEWW), 21st ed.(2005) while Alkalinity (Carbonate and Bicarbonate), chloride, magnesium, and calcium were measured using the standard Ethylene Diamine Tetraacetic Acid (EDTA). Unstable parameters such as $\mathrm{pH}$, total dissolved solids (TDS), temperature, and electrical conductivity (EC) were measured directly in the field using HQ40D portable multimeter ( $\mathrm{HACH}$, USA) during the sample collection. Different groundwater parameters gathered from six sampling wells in the study area were mapped and interpolated using Inverse Distance Weighting (IDW) with the 2nd power. The number of columns and rows were set at 5000 for the output map to enhance the quality of the images Using QGIS software. 
Table 1. Different methods used in the study

\begin{tabular}{cll}
\hline \multicolumn{1}{c}{ Indices } & Method/Equation & Sources \\
\hline Alkalinity hazard & $\begin{array}{l}\text { SAR }=\frac{N a}{\sqrt{(C a+M g) / 2}} \\
A d j . S A R=S A R(1+8.4-p H c)\end{array}$ & $\begin{array}{l}\text { (Nwankwo \& Ogagarue, 2011) } \\
\text { (Ayodele \& Aturamu, 2011) } \\
\text { (Srinivasa Rao et al., 2012) }\end{array}$ \\
\hline Sodium hazard) & $\mathrm{SSP}=\frac{\mathrm{Na}+K}{\mathrm{Ca}+\mathrm{Mg}+\mathrm{Na}+\mathrm{K}} \times 100$ & $\begin{array}{l}\text { (Narsimha, A and Sudarshan, 2013) } \\
\text { (Adimalla et al., 2018) }\end{array}$ \\
\hline Magnesium hazard & $\mathrm{MH}=\frac{\mathrm{Mg}}{\mathrm{Mg}+\mathrm{Ca}} \times 100$ & (District et al., 2013) \\
\hline Bicarnonate hazard & $\begin{array}{l}\mathrm{RSC}=\left(\mathrm{CO}_{3}{ }^{2-}+\mathrm{HCO}_{3}{ }^{-}\right)-\left(\mathrm{Ca}^{2+}\right. \\
\left.+\mathrm{Mg}^{2+}\right)\end{array}$ & (Rajesh et al., 2012) \\
\hline
\end{tabular}

Table 2. Standard water quality quidelines for irrigation (FAO, 1994)

\begin{tabular}{|c|c|c|}
\hline Parameters & Level & Class/degree of restriction \\
\hline \multirow{3}{*}{$\mathrm{EC}(\mu \mathrm{mhos} / \mathrm{cm})$} & $(<700)$ & No restriction on use \\
\hline & $700-3.000$ & Slight to moderate restriction on use \\
\hline & $>3.000$ & Unsuitable \\
\hline \multirow{3}{*}{ SAR } & $<3$ & None \\
\hline & 3 to 9 & Slight to moderate restriction on use \\
\hline & $>9$ & Severe \\
\hline \multirow{2}{*}{ SSP (\%) } & $<60$ & Suitable \\
\hline & $>60$ & Unsuitable \\
\hline \multirow{2}{*}{$\mathrm{MH}(\%)$} & $<50$ & Suitable \\
\hline & $>50$ & Unsuitable \\
\hline \multirow{3}{*}{$\mathrm{RSC}$ (meq/L) } & $<1.25$ & Suitable \\
\hline & $1.25-2.5$ & Marginally suitable \\
\hline & $>2.5$ & Unsuitable \\
\hline \multirow{3}{*}{ Chloride (mg/L) } & $<140$ & None \\
\hline & $140-350$ & Slight to moderate \\
\hline & $>350$ & Severe \\
\hline \multirow{2}{*}{ Calcium (mg/L) } & $<200$ & Suitable \\
\hline & $>200$ & Unsuitable \\
\hline \multirow{2}{*}{ Magnesium (mg/L) } & $<200$ & Suitable \\
\hline & $>200$ & Unsuitable \\
\hline $\mathrm{pH}$ & $6.5-8.5$ & Normal range \\
\hline
\end{tabular}




\section{RESULTS AND DISCUSSION}

\section{A. Salinity}

The EC values ranges from 86 to 1,604 $\mu \mathrm{mhos} / \mathrm{cm}$ with a mean of 531.7 $\mu \mathrm{mhos} / \mathrm{cm}$ (Table 3). Based on salinity classification (Table 2), two sampling wells (SW4 and SW6) in Lukbuton have EC values fall within $700-3000 \mu \mathrm{mhos} / \mathrm{cm}$ which require slight to moderate restriction use while the rest of sampling wells showed no restriction. It means that the groundwater in the study area still be safe for irrigation but with little salinity hazard for sensitive crops.

The spatial distribution of EC as shown in Figure $3 a$ indicated that the groundwater on the southern part of the island is safe for irrigation, while in the northern part of the study area which covered 222.29 ha $(23.48 \%)$ is slightly saline. There was an indication of saltwater intrusion from the northern tip of the island. When used for irrigation, the groundwater from this area may result to a salt build up in soil if proper drainage is not provided.

\section{B. Calcium Hazard}

The high concentrations of calcium were obtained in the same sampling well (SW6) in Lukbuton with values of 13.50 meq/L (Table 3 ). The least concentration of calcium was obtained from the sampling wells 1 and 5 in Santa Barbara with a value of $1.50 \mathrm{meq} / \mathrm{L}$. Based on the FAO (1994) standard (Table 2), the concentration of calcium at sampling well (SW6) was "unsuitable" for irrigation. The spatial distributions of calcium on the groundwater (Figure $3 \mathrm{~b}$ ) showed that only an area of 24.21 ha $(2.88 \%)$ has calcium concentration greater than $10 \mathrm{meq} / \mathrm{L}$ which is deemed unsuitable for agricultural use while the other 922.6 ha (97.44\%) of the area is safe for irrigation. Calcium was concentrated at Lukbuton village due to saltwater intrusion coming from the northern tip of the island. The maps provided viable information which site is suitable for a shallow well installation.

\section{Sodium Adsorption Ratio (SAR)}

In the presence of moisture and exchangeable sodium, the clay particles disperse rather than cling together as small peds (friable soil aggregates). This reduces water movement (permeability) and aeration in the soil. Soils with poor structure will have a coarse blocky or powdery texture and surface crusts formation after the rain or irrigation (Carvalho et al., 2008).

Excessive sodium causes the soil to be alkaline (Kelly, 1951). Moreover, a large amount of sodium in irrigation water is detrimental to plant growth by poisoning sodium-sensitive plants when absorbed by either roots or leaves (Begum and Rasul, 2009; Carvalhoet al., 2008). The groundwater on the island has sodium concentrations ranging from $0.26 \mathrm{meq} / \mathrm{L}$ to $2.18 \mathrm{meq} / \mathrm{L}$. These values were far below the allowable sodium concentration of $8.0 \mathrm{meq} / \mathrm{L}$ (Galal, 2015) that indicates no restriction on groundwater use for irrigation. The Sodium Adsorption Ratio (SAR) is commonly used as an index for evaluating the sodium hazard associated with irrigation water supply(S. M. Lesch, \& D. L. Suarez,2009). Irrigation water having high SAR levels can lead to the build-up of high soil sodium levels over time, which in turn can adversely affect soil infiltration and 
percolation rates (due to soil dispersion). Additionally, excessive SAR levels can lead to soil crusting, poor seedling emergence, and poor aeration (S. M. Lesch, \& D. L. Suarez,2009). The presence of bicarbonate and carbonate ions in the irrigation water increases the permeability hazard as quantified by SAR resulting to a modified adjusted SAR. Adjusted SAR is providing a more accurate index of water sodicity and dispersion risk (Bauder et al., 2008).

The values of SAR in the study area ranges from 0.24 to 0.89 while the computed and adjusted SAR ranges from 24.86 to 0.76 . SAR spatial distribution was displayed in Figure 3c. Most areas in Santa Barbara, Diki and about half of the areasin Lukbuton total of 708.44 ha or $74.82 \%$ ) have a computed SAR values ranging from 0.25 to 0.50 . Higher SAR values fall within the range of $0.75-0.90$ covered a small areas of 21.25 ha $(2.24 \%)$. SAR values tend to increase towards Lukbuton area. Based on SAR classification, all computed and adjusted SAR values of groundwater samples were less than 3 which means that the groundwater in the study area was suitable for irrigation.

\section{Soluble sodium percentage (SSP)}

The Soluble Sodium Percent (SSP) values less than 60 or equal to 60 indicate good water quality whilst SSP with more than 60indicates unsuitable water quality for irrigation (K. Nag, S., \& Das, S.,2014) (see Table 2). Spatial distribution of SSP on the groundwater (Figure $3 \mathrm{~d}$ ) indicated that 710.76 ha $(75.09 \%)$ of the study area have SSP values ranging from $10 \%$ to $12 \%$. The computed values of SSP of water samples taken from the study area ranged from $4.48 \%$ to $15.70 \%$ (Table 3 ). Irrigation water having SSP greater than $60 \%$ may result insodium accumulations that will cause dispersion of soil aggregate into their constituent individual soil particles. Based on the results and Table 2, the SSP percentages of all sampling wells in the study area were far below the limit and were suitable for irrigation.

\section{E. Magnesium hazard}

From Table 2,if magnesium hazard percentage is less than 50 , then water is safe and suitable for irrigation. The magnesium hazard in the study area ranged from $25 \%$ to $62.5 \%$ (Table 3 ). Unfortunately, two sampling wells (SW1 and SW3) in Santa Barbara and Lukbuton have computed values of $62.5 \%$, which means that those areas were considered unsafe and unsuitable for irrigation. Spatial distribution of magnesium hazard (Figure 4a) showed that 887.37 ha (93.72\%) of the study area's groundwater is free from magnesium hazard and only 59.45 ha $(6.28 \%)$ is unsuitable for irrigation.

\section{F. Residual sodium carbonate (RSC)}

Irrigation water having high bicarbonate concentration tends to precipitate the calcium and magnesium ions as carbonate. The effect of carbonate and bicarbonate ions on the quality of water was expressed in terms of the Residual Sodium Carbonate (Eaton,1950). The Residual Sodium Carbonate (RSC) is considered as another hazard when reach a value of $2.5 \mathrm{meq} / \mathrm{L}$ (see Table 2). The study area's RSC ranges from -7.85 to $0.12 \mathrm{meq} / \mathrm{L}$ (Table 3). Out of the 6 samples, 5 water samples have negative RSC values. This indicates that the sum of calcium and magnesium ions is greater than the sum of carbonate and 
bicarbonate. Based on the RSC classification, all the sampling wells were classified as safe or suitable for irrigation.

\section{G. Chloride Hazard}

Chloride ion is not held back by soils due to its negative charge, therefore it moves steadily with water. High chloride concentration on the irrigation water can cause wilting (burning) on the plant's leaves. Wilting starts at the older tips of the leaves and progresses backwards as the severity increases. Chloride concentration ranges from $0.14-6.34$ $\mathrm{meq} / \mathrm{L}$ with mean and standard deviation values and degree of restriction shown in Table 3. Higher chloride concentration was observed at sampling well SW4 in Lukbuton which is categorized as "slight to moderate use" while the rest have "no restriction on irrigation use."

The spatial distribution of chloride (Figure 4b) showed a substantial increase of chloride concentrations on the groundwater towards the northern part of the island. More than $50 \%$ of the area situated between Lukbuton and Santa Barbara has chloride concentrations from 1 - $2 \mathrm{meq} / \mathrm{L}$, and only $4.43 \%$ of the area which is 41.97 ha has higher chloride concentrations greater than $3 \mathrm{meq} / \mathrm{L}$. The groundwater from any well within this surrounded area should be used sparingly or moderately for irrigation to prevent chloride hazards. Sampling wells with higher EC and TDS values have also higher chloride values since they were related to each other.

Table 3. Concentrations of various measured water quality parameters of groundwater of Malamawi island, Isabela City, Basilan March 2015

\begin{tabular}{lrrrrrrrrrr}
\hline $\begin{array}{c}\text { Sampling } \\
\text { Wells }\end{array}$ & $\begin{array}{r}\text { Sodium } \\
(\mathrm{mg} / \mathrm{L})\end{array}$ & $\begin{array}{c}\text { Potassium } \\
(\mathrm{mg} / \mathrm{L})\end{array}$ & $\begin{array}{c}\text { Calcium } \\
(\mathrm{mg} / \mathrm{L})\end{array}$ & $\begin{array}{r}\text { Magnesium } \\
(\mathrm{mg} / \mathrm{L})\end{array}$ & $\begin{array}{c}\text { SAR } \\
\text { SW1 }\end{array}$ & $\begin{array}{r}\text { SSP } \\
\%\end{array}$ & $\begin{array}{r}\text { Hazard } \\
\%\end{array}$ & $\begin{array}{c}\text { Bicarbonate } \\
(\mathrm{mg} / \mathrm{L})\end{array}$ & $\begin{array}{c}\text { RSC } \\
(\mathrm{meq} / \mathrm{L})\end{array}$ & $\begin{array}{c}\text { Chloride } \\
(\mathrm{mg} / \mathrm{L})\end{array}$ \\
SW2 & 8,74 & 0,39 & 50,10 & 25,21 & 0,29 & 10,48 & 24,99 & 210,51 & 0,12 & 4,96 \\
SW3 & 22,77 & 0,86 & 50,10 & 50,67 & 0,54 & 13,19 & 62,5 & 233,08 & $-2,85$ & 19,82 \\
SW4 & 50,14 & 2,15 & 140,28 & 60,75 & 0,89 & 15,7 & 41,67 & 677,90 & $-0,89$ & 224,44 \\
SW5 & 5,98 & 0,47 & 30,06 & 10,08 & 0,24 & 10,36 & 35,71 & 79,93 & $-1,03$ & 9,91 \\
SW6 & 20,47 & 0,78 & 270,54 & 70,83 & 0,29 & 4,48 & 30,17 & 700,47 & $-7,85$ & 35,06 \\
\hline Mean & 19,90 & 0,85 & 95,19 & 41,32 & 0,43 & 10,88 & 42,92 & 347,59 & $-2,25$ & 50,68 \\
SD & 14,81 & 0,61 & 86,92 & 21,18 & 0,23 & 3,42 & 14,74 & 246,32 & 2,65 & 78,32 \\
\hline
\end{tabular}



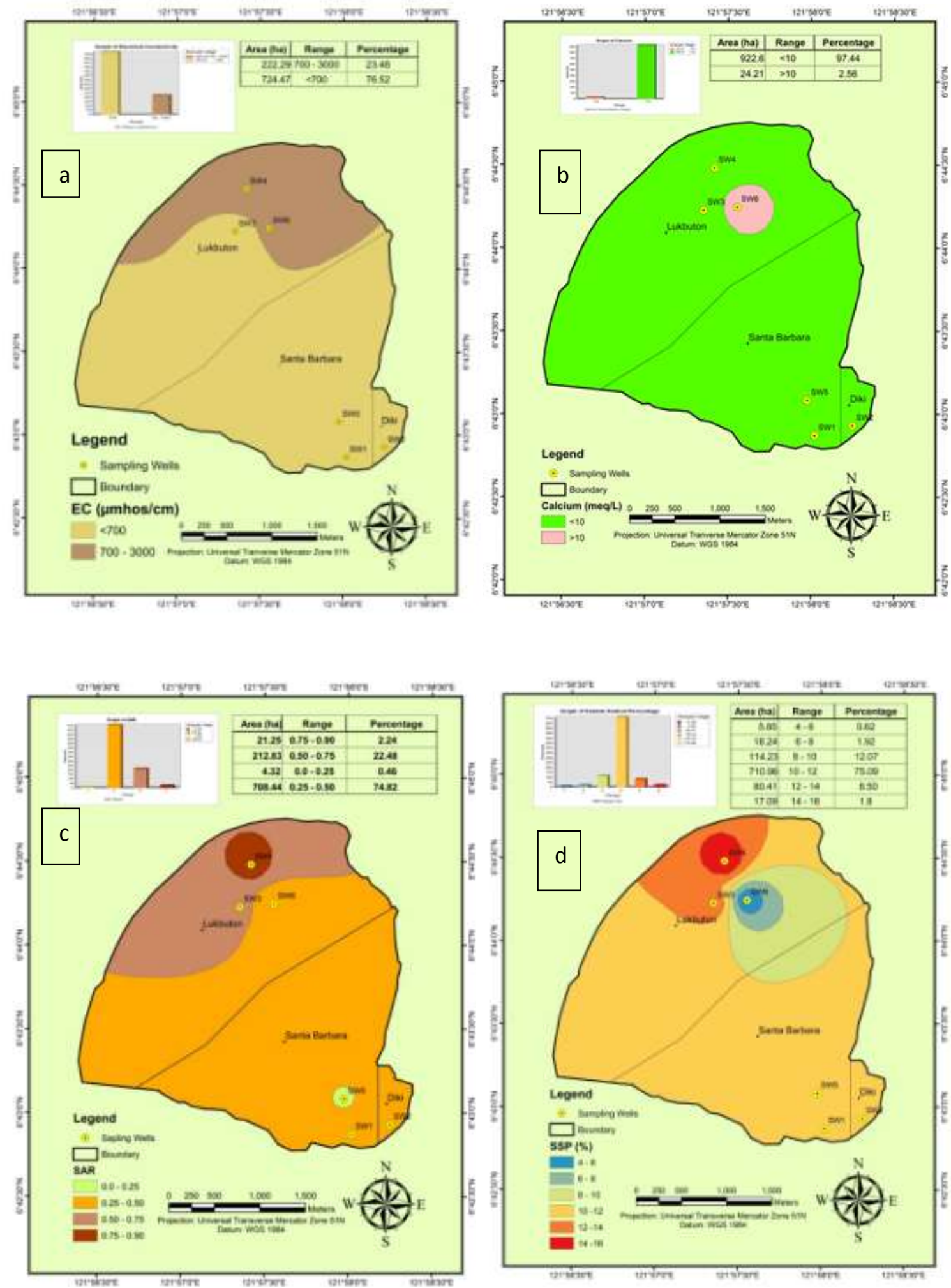

Figure 3. Spatial distribution of groundwater quality parameters (March 2015), a. Electrical conductivity (EC), b. Calcium, c. SAR, d.SSP of Malamawi island, Isabela City, Basilan, Zamboanga Peninsula, Philippines 

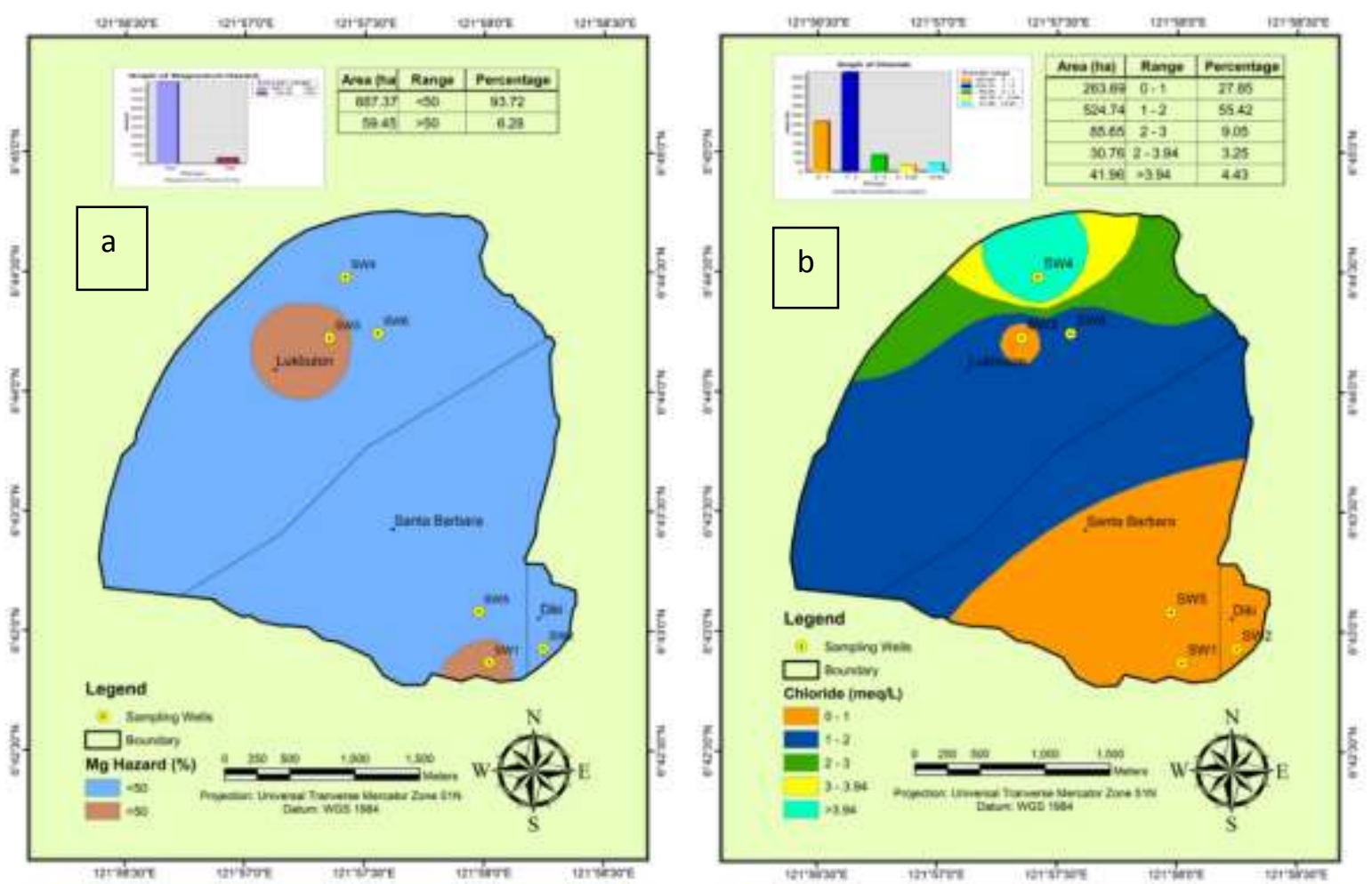

Figure 4. Spatial distribution of groundwater quality parameters (March 2015), a. Magnesium hazard, b. Chloride of Malamawi island, Isabela City, Basilan, Zamboanga Peninsula, Philippines

\section{CONCLUSIONS}

In terms of salinity level, the north eastern part of Lukbuton requires some management because it showed a slightly poor groundwater quality for irrigation, while the rest of the area is in good quality. The alkalinity levels that based on SAR, SSP, and $\mathrm{RSC}$, on the other hand, all study area was suitable for irrigation. The magnesium hazard level in the sampling wells 1 and 3 indicates slightly poor quality, while in terms of chloride hazard, all sampling wells except SW4 shows "no restriction on irrigation use" based on chloride classification. In the sampling well 4 high chloride concentration was observed, which was categorized as "slight to moderate use" for irrigation.

\section{ACKNOWLEDGMENT}

Special thanks are to the following: Commission on Higher Education (CHED), Philippines for the scholarship grant, members of my guidance committee Dr. Roger A. Luyun Jr., Dr. Aurelio A. Delos Reyes Jr., Prof. Victorino A. Bato for their scholarly suggestions and guidance, our college president Dr. Nasser A. Salain for his moral and academic support.

\section{REFERENCES}

Adimalla, N., Dhakate, R., Kasarla, A., \& Taloor, A. K. (2020). Appraisal of groundwater quality for drinking and irrigation purposes in Central Telangana, India. Groundwater for Sustainable Development, 10(126), 100334. https://doi.org/10.1016/j.gsd.2020.1003 34

Adimalla, N., Li, P., \& Qian, H. (2019). Evaluation of groundwater contamination for fluoride and nitrate in semi-arid region of Nirmal Province, South India: A special emphasis on human health risk assessment (HHRA). Human and Ecological Risk Assessment, 
25(5),

1107-1124.

https://doi.org/10.1080/10807039.2018. 1460579

Alobaidy, A. H. M. J., Abid, H. S., \& Maulood, B. K. (2010). Application of Water Quality Index for Assessment of Dokan Lake Ecosystem, Kurdistan Region, Iraq. Journal of Water Resource and Protection, 02(09), 792-798. https://doi.org/10.4236/jwarp.2010.290 93

Ayodele, O. S., \& Aturamu, A. O. (2011). Portability Status of Some Hand Dug Wells in Ekiti State, Southwestern Nigeria Hydrogeological Setting of the Study Area. International Journal of Science and Technolog, 1(2), 102-109

Bangsamoro Development Agency. (2016). Comprehensive Capacity Development Project for the Bangsamoro Development Plan for the Bangsamoro Final Report Sec.

Bauder, J. W., Bauder, T. a, Waskom, R. M., \& Scherer, T. F. (2008). Assessing the Suitability of Water ( Quality ) for Irrigation - Salinity and Sodium. 1-5

Begum, S., Rasul, M.G. Reuse of Stormwater for Watering Gardens and Plants Using Green Gully: A New Stormwater Quality Improvement Device (SQID). Water Air Soil Pollut: Focus 9, 371 (2009). https://doi.org/10.1007/s11267-0099226-x

Carvalho, L., Spears, B., Dudley, B., Gunn, I., Zimmermann, S., Defew, L., \& May, L. (2008). Loch Leven 2007: trends in water quality and biological communities. July 2015. http://nora.nerc.ac.uk/3017/

District, W., Pradesh, A., Narsimha, A., Sudarshan, V., \& Swathi, P. (2013). Groundwater and Its assessment for Irrigation purpose in Hanmakonda Area, Warangal District, Andhra Pradesh, India. International Journal of Research in Chemistry and Environment, 3(2), 196-200.

Eaton, F.M. (1950) Significance of Carbonates in Irrigation Waters. Soil Science, 69, 123-134.

https://doi.org/10.1097/00010694195002000-00004

FAO. 1994, Water quality for agriculture, http://www.fao.org/docrep/x5871e/x58 71e07.htm

Galal, H. A. A. (2015). Long-term Effect of Mixed Wastewater Irrigation on Soil Properties, Fruit Quality and Heavy Metal Contamination of Citrus. 3(3), 100-105. https://doi.org/10.12691/env3-3-6

Iqbal, A. B., Rahman, M. M., Mondal, D. R., Khandaker, N. R., Khan, H. M., Ahsan, G. U., Jakariya, M., \& Hossain, M. M. (2020). Assessment of Bangladesh groundwater for drinking and irrigation using weighted overlay analysis. Groundwater for Sustainable Development, 10(September 2019), 100312.

https://doi.org/10.1016/j.gsd.2019.1003 12

Iqbal, H. H., Shahid, N., Qadir, A., Ahmad, S. R., Sarwar, S., Ashraf, M. R., Arshad, H. M., \& Masood, N. (2017). Hydrological and ichthyological impact assessment of rasul barrage, river jhelum, Pakistan. Polish Journal of Environmental Studies, 26(1), 107-114. https://doi.org/10.15244/pjoes/63877

Jang, C. S., Chen, S. K., \& Kuo, Y. M. (2012). Establishing an irrigation management plan of sustainable groundwater based on spatial variability of water quality and quantity. Journal of Hydrology, 414-415, 201-210.

https://doi.org/10.1016/j.jhydrol.2011.1 0.032

Jang, C. S., Kuo, Y. M., \& Chen, S. K. (2019). 
Assessment of shallow groundwater use for irrigating park trees in the metropolitan Taipei Basin according to variability conditions of water quality. Journal of Hydrology X, 2, 100013. https://doi.org/10.1016/j.hydroa.2018.1 00013

Kelly, P. (1951). Alkali soils: Their formation properties and reclamation," Reinhold, New York

K. Nag, S., \& Das, S. (2014). Quality Assessment of Groundwater with Special Emphasis on Irrigation and Domestic Suitability in Suri I \&amp; II Blocks, Birbhum District, West Bengal, India. American Journal of Water Resources, 2(4), 81-98. https://doi.org/10.12691/ajwr-2-4-2

Khanoranga, \& Khalid, S. (2019). An assessment of groundwater quality for irrigation and drinking purposes around brick kilns in three districts of Balochistan province, Pakistan, through water quality index and multivariate statistical approaches. Journal of Geochemical Exploration, 197(November 2018), 14-26. https://doi.org/10.1016/j.gexplo.2018.1 1.007

Kuldip-Singh, Hundal, H. S., \& DhanwinderSingh. (2011). Geochemistry and assessment of hydrogeochemical processes in groundwater in the southern part of Bathinda district of Punjab, northwest India. Environmental Earth Sciences, 64(7), 1823-1833. https://doi.org/10.1007/s12665-0110989-9

Mitra, B. K., Sasaki, C., Enari, K., Matsuyama, N., \& Pongpattanasiri, S. (2007). Suitability assessment of shallow groundwater for irrigation in sand dune area of northwest Honshu island, Japan. International Journal of Agricultural Research, 2(6), 518-527. https://doi.org/10.3923/ijar.2007.518.5 27

Narsimha, A and Sudarshan, V. (2013). Hydrogeochemistry of groundwater in Basara area, Adilabad District, Andhra Pradesh, India. Journal of Applied Geochemistry, 15(February 2020), 224. https://scholar.googleusercontent.com/ scholar.bib?q=info:dVx5IZUTJpsJ:scholar. google.com/\&output=citation\&scisig=AA GBfm0AAAAAWroUjMp_ysS_M5zG67DIgPZtXlq1kWh\&scisf=4\&ct=citatio $\mathrm{n} \& \mathrm{~cd}=-1 \& \mathrm{hl}=\mathrm{en}$

Naseh, M. R. V., Noori, R., Berndtsson, R., Adamowski, J., \& Sadatipour, E. (2018). Groundwater pollution sources apportionment in the ghaen plain, Iran. International Journal of Environmental Research and Public Health, 15(1). https://doi.org/10.3390/ijerph15010172

Nawab, J., Khan, S., Ali, S., Sher, H., Rahman, Z., Khan, K., Tang, J., \& Ahmad, A. (2016). Health risk assessment of heavy metals and bacterial contamination in drinking water sources: a case study of Malakand Agency, Pakistan. Environmental Monitoring and Assessment, 188(5). https://doi.org/10.1007/s10661-0165296-1

Nawab, J., Khan, S., Xiaoping, W., Rahman, A., Ali, H., Qamar, Z., Khan, Z. A., Rehman, Z. ur, Rahman, H., Muhammad, J., Khan, A., \& Shah, I. A. (2018). Spatial distribution of toxic metals in drinking water sources and their associated health risk in district buner, Northern Pakistan. Human and Ecological Risk Assessment, 24(3), 615626.

https://doi.org/10.1080/10807039.2017. 1395684

Nwankwo, C. N., \& Ogagarue, D. O. (2011). Effects of gas flaring on surface and ground waters in Delta State Nigeria. Journal of Geology and Mining Research, 3(May), 131-136. 
Philippine-National-Standards-for-Drinking-

Water (PNSDW)-2017-DOH-AO-20170010,

www.scribd.com/document/382076313

Rajesh, R., Brindha, K., Murugan, R., \& Elango, L. (2012). Influence of hydrogeochemical processes on temporal changes in groundwater quality in a part of Nalgonda district, Andhra Pradesh, India. Environmental Earth Sciences, 65(4), 1203-1213.

https://doi.org/10.1007/s12665-0111368-2

S. M. Lesch, \& D. L. Suarez. (2009). Technical Note: A Short Note on Calculating the Adjusted SAR Index. Transactions of the ASABE, 52(2), 493-496. https://doi.org/10.13031/2013.26842
Singh, V., \& Khare, M. C. (2008). Groundwater quality evalution for irrigation purpose in some areas of Bhind, Madhya Pradesh (India). Journal of Environmental Research And Development, 2(3), 347-356.

Srinivasa Rao, V., Prasanthi, S., Shanmukha K, J. V., \& Prasad, K. R. S. (2012). Physicochemical analysis of water samples of nujendla area in Guntur District, Andhra Pradesh, India. International Journal of ChemTech Research, 4(2), 691-699.

Woodworth, J., \& Stednick, J. (2011). Estimation of Unconfined Aquifer Hydraulic Properties Using Gravity and Drawdown Data. 